\title{
TINGKAT PENGETAHUAN IBU HAMIL TRIMESTER II TENTANG KEBUTUHAN NUTRISI
}

\author{
Ika Fitria Ayuningtyas dan Hafifah Wijayanti \\ Program Studi Kebidanan STIKES Jenderal Achmad Yani Yogyakarta
}

\begin{abstract}
Background : Pregnant mothers' nutritional status is partly influenced by knowledge level. Early study signaled that there were $47,25 \%$ of pregnant mothers who suffered Chronic Energy Deficiency and the result of interviews found out that 7 out of 10 pregnant mothers had insufficient understanding about nutritional need. This fact encouraged the researcher to hold a study about the knowledge level of second term pregnant mothers about nutritional need in Sanden Community Health Center, Bantul, Yogyakarta
\end{abstract}

Objective : To uncover the knowledge level of second term pregnant mothers about nutritional intake need in Sanden Community Health Center, Bantul, Yogyakarta

Method : This was a quantitative descriptive study. Population in this study was Second Term pregnant mothers who underwent pregnancy examination in Sanden Community Health Center, Bantul, Yogyakarta, during June - July 2014. 30 respondents were sorted with Incidental Sampling technique. Data collecting used primary data and the instrument used was closed questionnaire.

Result : This study finally categorized the knowledge level of pregnant mothers in Good category $(33,3 \%)$, Sufficient category $(60,0 \%)$, and Poor category $(6,7 \%)$.

Conclusion : The knowledge level of second term pregnant mothers about nutritional need were categorized as enough so that it is recommended that pregnant mothers improve their understanding about nutritional need during pregnancy.

Suggestion : Midwives in Community Health Centre are supposed to hold dissemination about nutritional need during pregnancy so that it may prevent any Chronic Energy Deficiency.

Keywords : Nutritional Need, Pregnancy

\section{PENDAHULUAN}

Saat ini status kesehatan ibu dan anak di Indonesia masih jauh dari yang diharapkan, sebagian besar penduduk Indonesia saat ini dapat dikatakan tidak sakit akan tetapi juga tidak sehat, umumnya disebut kekurangan gizi. Berbagai masalah gizi seperti gizi kurang, gizi buruk, kurang vitamin $A$, anemia gizi besi, gangguan akibat kurang iodium, dan gizi lebih (obesitas) masih banyak tersebar di kota dan desa di seluruh tanah air. Kejadian kekurangan gizi pada ibu hamil berdampak pada kemungkinan risiko tinggi untuk melahirkan bayi dengan berat badan lahir rendah (BBLR), meningkatnya kemungkinan pre eklamsi, perdarahan antepartum, dan komplikasi obstetrik lainya selain meningkatnya angka kematian ibu, angka kematian perinatal, angka kematian bayi, angka kematian balita, serta rendahnya umur harapan hidup (Depkes RI, 2009).

Status gizi ibu hamil dapat dipengaruhi oleh keadaan sosial ekonomi dan keadaan kesehatan ibu hamil selama kehamilan. Secara umum penyebab kekurangan gizi pada ibu hamil karena konsumsi makanan yang tidak memenuhi 
syarat pemenuhan gizi. Tingkat pengetahuan yang rendah menyebabkan ibu tidak mengerti cara pemenuhan nutrisi yang dibutuhkan ibu hamil selama kehamilannya (Depkes RI, 2003). Faktorfaktor yang memengaruhi keadaan tersebut antara lain tingkat kemampuan keluarga dalam menyediakan pangan sesuai dengan kebutuhan anggota keluarga, pengetahuan dan perilaku keluarga dalam memilih, mengolah dan membagi makanan ditinggkat rumah tangga, ketersediaan air bersih dan fasilitas sanitasi dasar serta ketersediaan dan aksebilitas terhadap pelayanan kesehatan dan gizi masyarakat yang berkualitas serta perilaku masyarakat terhadap gizi keluarga.

Menurut penelitian yang dilakukan di Boston tahun 2005 menunjukkan bahwa ibu hamil dengan kurang gizi dapat melahirkan bayi lahir mati, meninggal setelah beberapa hari lahir, dan bayi lahir dengan kecacatan (Hariyani, 2012). Selain itu dapat berisiko abortus, bayi lahir dengan berat badan rendah, dan retardasi mental. Lingkar lengan atas dapat menunjukkan status nutrisi ibu hamil, lingkar lengan atas $<23,5 \mathrm{~cm}$ menunjukkan status nutrisi ibu hamil kurang (Hariyani, 2012). Menurut Depkes RI (2009) Kejadian kekurangan gizi pada ibu hamil berdampak pada kemungkinan risiko tinggi untuk melahirkan bayi dengan berat badan lahir rendah (BBLR), meningkatnya kemungkinan pre eklamsi, perdarahan antepartum, dan komplikasi obstetrik lainya selain meningkatnya angka kematian ibu, angka kematian Menurut badan kesehatan dunia WHO melaporkan bahwa ibu hamil yang mengalami defisiensi besi sekitar 35-75\% (Paendong, 2016). Prevalensi ibu hamil di wilayah DIY dengan kekurangan energi kronis masih cukup tinggi. Pada tahun 2012 di wilayah kabupaten Bantul didapatkan ada tiga puskesmas yang memunyai prevalensi ibu hamil dengan kekurangan energi kronis cukup tinggi yaitu Sanden (47,25\%), Jetis 1 (43,67\%), dan Kasihan 1 (44.54\%). perinatal, angka kematian bayi, angka kematian balita, serta rendahnya umur harapan hidup. Apabila status gizi ibu hamil baik, maka janin yang dikandungnya akan baik juga dan kesehatan ibu sewaktu melahirkan akan terjamin. Sebaliknya jika keadaan kesehatan dan status gizi ibu hamil kurang, maka akan dapat berakibat janin lahir mati (perenatal death) dan bayi lahir dengan berat badan kurang dari normal (low birth weight) yang dikenal dengan istilah berat badan lahir rendah (Kristiyanasari, 2010).

Masa kehamilan merupakan masa yang sangat menetukan kualitas sumber daya manusia masa depan, karena tumbuh kembang anak sangat ditentukan kondisinya dimasa janin dalam kandungan. Salah satu faktor yang memengaruhi terhadap kesehatan ibu adalah keadaan gizi ibu (Depkes RI, 2007). Status gizi merupakan ukuran keberhasilan dalam pemenuhan nutrisi untuk ibu hamil. Gizi ibu hamil merupakan nutrisi yang diperlukan dalam jumlah yang banyak untuk pemenuhan gizi ibu sendiri dan perkembangan janin yang dikandungnya (Bobak, dkk, 2005). Kebutuhan makanan dilihat bukan hanya dalam porsi yang dimakan tetapi harus ditentukan pada mutu zat-zat gizi yang terkandung dalam makanan yang dikonsumsi (Amiruddin, 2007). WHO (World Health Organization) menganjurkan jumlah tambahan sebesar $150 \mathrm{Kkal}$ sehari pada trimester I, dan 350 Kkal sehari pada trimester II dan III (Waryana, 2010).

\section{METODE PENELITIAN}

Jenis penelitian yang digunakan adalah penelitian kuantitatif dengan pendekatan observasional. Alat Ukur menggunakan kuesioner dengan jumlah pernyataan 23 buah. Subjek dalam penelitian ini diambil dengan cara accidental sampling pada 30 ibu hamil trimester II yang melakukan pemeriksaan kehamilan di Puskesmas Sanden Bantul pada bulan Juni s.d. Juli 2014. Analisis data berupa analisis univariat. 


\section{HASIL PENELITIAN}

Tabel 1. Tabel Silang Karakteristik Responden dengan Tingkat Pengetahuan Ibu Hamil Trimester II Tentang Kebutuhan Nuttrisi di Puskesmas Sanden, Bantul, Yogyakarta.

\begin{tabular}{|c|c|c|c|c|c|c|c|}
\hline \multirow{3}{*}{ Karakteristik } & \multicolumn{5}{|c|}{ Tingkat Pengetahuan } & \multirow{2}{*}{\multicolumn{2}{|c|}{ Total }} \\
\hline & \multicolumn{2}{|c|}{ Baik } & \multicolumn{2}{|c|}{ Cukup } & Kurang & & \\
\hline & $f$ & $\%$ & $f$ & $\%$ & $f \%$ & $f$ & $\%$ \\
\hline \multicolumn{8}{|l|}{ Umur } \\
\hline$<20$ tahun & 1 & 3,33 & 2 & 6,67 & 0 & 3 & 10,0 \\
\hline 20-35 tahun & 9 & 30,00 & 11 & 36,67 & 26,67 & 22 & 73,33 \\
\hline$>35$ tahun & 0 & 0 & 5 & 16,7 & 0 & 5 & 16,66 \\
\hline Total & 10 & 33,3 & 18 & 60,0 & 26,7 & 30 & 100,0 \\
\hline \multicolumn{8}{|l|}{ Pendidikan } \\
\hline Dasar & 0 & 0 & 3 & 10,00 & 13,33 & 4 & 13,33 \\
\hline Menengah & 8 & 26,67 & 15 & 50,00 & 13,33 & 24 & 80,00 \\
\hline Tinggi & 2 & 6,67 & 0 & 0 & 0 & 2 & 16,66 \\
\hline Total & 10 & 33,3 & 18 & 60,0 & 26,7 & 30 & 100,0 \\
\hline \multicolumn{8}{|l|}{ Pekerjaan } \\
\hline Bekerja & 5 & 16,7 & 5 & 16,7 & 0 & 10 & 33,33 \\
\hline Tidak bekerja & 5 & 16,7 & 13 & 43,33 & 326,67 & 20 & 66,66 \\
\hline Total & 10 & 33,3 & 18 & 60,0 & 26,7 & 30 & 100,0 \\
\hline
\end{tabular}

Data Primer (2014)

Dari tabel diatas dapat dilihat bahwa sebagian besar berpengetahuan cukup sebanyak 18 responden $(60,0 \%)$, mayoritas berumur 20-35 tahun sebanyak 11 responden $(36,67 \%)$, berpendidikan menengah sebanyak 15 responden $(50 \%)$ dan tidak bekerja sebanyak 13 responden (43,33\%).

Tabel 2. Tingkat Pengetahuan Ibu Hamil Trimester II Tentang Kebutuhan Nuttrisi di Puskesmas Sanden, Bantul, Yogyakarta.

\begin{tabular}{|c|c|c|c|c|c|c|c|c|}
\hline \multirow{3}{*}{ Kebutuhan Nutrisi } & \multicolumn{6}{|c|}{ Tingkat Pengetahuan } & \multirow{2}{*}{\multicolumn{2}{|c|}{ Total }} \\
\hline & \multicolumn{2}{|c|}{ Baik } & \multicolumn{2}{|c|}{ Cukup } & \multicolumn{2}{|c|}{ Kurang } & & \\
\hline & $f$ & $\%$ & $f$ & $\%$ & $f$ & $\%$ & $f$ & $\%$ \\
\hline Pengertian & 25 & 83,3 & 0 & 0 & 5 & 16,7 & 30 & 100 \\
\hline Tujuan penataan gizi & 9 & 30 & 0 & 0 & 21 & 70 & 30 & 100 \\
\hline Manfaat kebutuhan nutrisi & 9 & 30 & 0 & 0 & 21 & 70 & 30 & 100 \\
\hline Kebutuhan nutrisi & 18 & 60 & 3 & 10 & 9 & 30 & 30 & 100 \\
\hline Faktor yang memengaruhi & 10 & 33,3 & 12 & 40 & 8 & 26,7 & 30 & 100 \\
\hline Akibat gangguan gizi & 7 & 23,3 & 16 & 53,3 & 7 & 23,3 & 30 & 100 \\
\hline Nutrisi yang harus dihindari & 21 & 70 & 0 & 0 & 9 & 30 & 30 & 100 \\
\hline
\end{tabular}


Pengetahuan responden secara keseluruhan cukup tetapi jika dilihat dari tabel 2 terdapat pengetahuan baik pada pengertian sebanyak 25 responden $(80,3 \%)$, kebutuhan nutrisi sebanyak 18 responden $(60 \%)$, dan nutrisi yang harus dihindari sebanyak 21 responden $(70 \%)$, serta pengetahuan kurang pada tujuan penataan gizi dan manfaat kebutuhan gizi masing-masing sebanyak 21 responden (70\%).

\section{PEMBAHASAN}

Tingkat pengetahuan yang rendah menyebabkan ibu tidak mengerti cara pemenuhan nutrisi yang dibutuhkan ibu hamil selama kehamilannya (Depkes RI, 2003). Hasil penelitian menunjukkan sebagian besar responden berpengetahuan cukup yaitu sebanyak 18 responden $(60,0 \%)$, mayoritas berumur 20-35 tahun sebanyak 11 responden $(36,67 \%)$, berpendidikan menengah sebanyak 15 responden (50\%) dan tidak bekerja sebanyak 13 responden (43,33\%). Meskipun pengetahuan responden secara keseluruhan cukup tetapi jika dilihat dari isi kebutuhan nutrisi terdapat pengetahuan baik pada pengertian sebanyak 25 responden $(80,3 \%)$, kebutuhan nutrisi sebanyak 18 responden $(60 \%)$, dan nutrisi yang harus dihindari sebanyak 21 responden (70\%), serta pengetahuan kurang pada tujuan penataan gizi dan manfaat kebutuhan gizi masing-masing sebanyak 21 responden (70\%).

Ibu hamil dengan tingkat sosial ekonomi yang baik, pada umumnya akan mendapatkan kesejahteraan fisik dan psikologis yang baik pula. Status gizipun akan meningkat karena asupan nutrisi yang didapatkan berkualitas. Tingkat sosial ekonomi terbukti sangat berpengaruh terhadap kondisi kesehatan fisik dan psikologis ibu hamil (Sulistyawati, 2009). Hasil penelitian menunjukkan bahwa sebagian besar responden adalah ibu rumah tangga (IRT). Kegiatan IRT tidak terlalu banyak menyita waktu sehingga tersedia waktu untuk memerhatikan kondisi keluarga namun dalam segi status ekonomi tergantung pada penghasilan suami. Penghasilan wanita pekerja memberikan kontribusi yang cukup signifikan terhadap penghasilan dan kesejahteraan keluarga (Parawansa, 2003).

Semakin muda dan semakin tua umur seorang ibu hamil, akan berpengaruh terhadap kebutuhan gizi yang diperlukan. Umur ibu hamil diatas 30 tahun perlu energi yang besar karena fungsi organ semakin melemah dan diharuskan bekerja maksimal maka memerlukan tambahan energi yang cukup guna mendukung kehamilan yang sedang berlangsung (Kristiyanasari, 2010), meskipun sebagian besar responden berpengetahuan cukup dalam usia reproduksi sehat tetapi ada juga responden yang berpengetahuan baik yaitu usia $<20$ tahun.

Tingkat pendidikan sangat berpengaruh terhadap pengetahuan dan perubahan sikap serta perilaku hidup sehat. Hasil penelitian ini menunjukkan bahwa 15 responden (50\%) berpendidikan menengah. Pendidikan dan sosial ekonomi yang rendah akan memengaruhi kemampuan keluarga dalam mencari fasilitas pelayanan kesehatan (Suhardjo, 2005). Pendidikan yang baik akan memermudah untuk mengadopsi pengetahuan tentang kesehatannya. Rendahnya tingkat pendidikan ibu hamil dapat menyebabkan keterbatasan dalam memenuhi kecukupan gizi dan upaya menangani masalah gizi dan kesehatan keluarga.

\section{SIMPULAN}

Sebagian responden berpengetahuan cukup meskipun jika dilihat secara rinci ada yang sebagian besar berpengetahuan baik dan kurang.

\section{DAFTAR PUSTAKA}

Amiruddin. 2007. Asupan Gizi Pada Ibu Hamil.http://www.scribd.com/doc/47 810533/makalah-anemi-bumil Diakses 15 Februari 2014. 
Bobak, M. Irene, at.al. 2005. Buku Ajar Keperawatan Maternitas, edisi 4. Alih Bahasa: Maria Wijayarini. Jakarta: EGC.

Depkes RI. 2003. Pedoman Umum Gizi Seimbang (Panduan Untuk Petugas).http://gizi.net/panduan/12p esan\%dasar\%giziseimabang.pdf. Diunduh tanggal 14 Juni 2014.

Depkes RI. 2007. Pedoman Strategi Keluarga Sadar Gizi (Kadarsi). http://gizi.net/kadarzi.pdf. Diunduh tanggal 15 Februari 2013.

Depkes Rl. 2009. Rancangan Pembangunan Jangka Panjang Bidang Kesehatan 2005-2025. http://www.depkes.go.id/dowloads/n ewdowloads/rancanganRPJPK Diunduh tanggal 14 Juni 2014.

Hariyani, S. 2012. Gizi untuk kesehatan ibu dan anak. Yogyakarta: Graha ilmu.
Kristiyanasari, W. 2010 Gizi Ibu Hamil cetakan I. Yogyakarta. Nuha Medika.

Paendong, Florencia T; Suparman, Edy; Tendean, Hermie, M,M. 2016. Profil Zat Besi (Fe) Pada lbu Hamil Dengan Anemia Di Puskesmas Bahu Manado. Jurnal e-Clinic (eCl), Volume 4, Nomor 1, Jamuari-Juni 2016.

Parawansa, KI. 2003. Pemberdayaan Perempuan Dalam Pembangunan Berkelanjutan. Makalah pada Seminar Nasional. Bali, 15 Juli 2003.

Suhardjo.2005. Perencanaan Pangan dan Gizi. Jakarta: Bumi Aksara.

Sulistyawati. 2009. Asuhan Kebidanan Pada Masa Kehamilan. Jakarta: Salemba Medika.

Waryana. 2010. Gizi Reproduksi. Yogyakarta. Pustaka Rihama. 